\title{
Daily atmospheric circulation patterns for Catalonia (northeast Iberian Peninsula) using a modified version of Jenkinson and Collison method
}

Authors: Miró Cubells, J.R.; Pepin, N.; Peña, JC; Martin-Vide, J.

Keywords: Synoptic Meteorology; synoptic classification; Iberian Peninsula; Cold Air Pool.

\begin{abstract}
The Western Mediterranean, in common with other subtropical regions, has certain characteristics that make a purely surface-based synoptic classification inadequate. Sometimes, despite the surface synoptic situation not being conducive to precipitation, a depression aloft can trigger convection and produce strong rains and flash floods. To account for this, we develop a new synoptic classification centred on Catalonia (northeast of the Iberian Peninsula) which combines upper air and surface pressure situations. The existing Jenkinson-Collison classification of the surface pressure field is combined with a new simplified upper air classification based on $500 \mathrm{hPa}$ geopotential height. Despite a reduced number of types at $500 \mathrm{hPa}$, the combination of both surface and 500 $\mathrm{hPa}$ gives many potential combinations. A reduction in the overall number was achieved by adjusting the combined classification to replicate the manual classification of MartinVide. The final classification is reduced to 13 synoptic patterns each of which provides a clear and well-defined daily synoptic situation. It is used to characterize days with/without cold air pool (CAP) events, derived from a network of 50 temperature sensors distributed across Cerdanya in Eastern Pyrenees. We show our new classification to be better at discriminating strong CAP days from no-CAP days than classifications based on surface pressure alone. Thus there is potential for the classification to be used by forecasters as a first step for predicting temperature inversions and weather in the Eastern Pyrenees.
\end{abstract}




\section{INTRODUCTION}

Although an increase in computation power has facilitated the use of high-resolution atmospheric circulation models to examine local climate problems, this does not displace the need for synoptic meteorology. Still today, forecasting routines usually include a synoptic point of view (Athar and Sara, 2014) and the general recommendation in forecasting protocols is to downscale predictions from synoptic to local scales, to take interactions between scales into account (Snellman, 1982; Lanicci, 2003).

In the light of a continuing need for a synoptic approach, the action COST-733 attempted to unify criteria for developing reference synoptic classifications stating that the best synoptic classification depended on the application (Philipp et al, 2010). The project subsequently became a critical reference in synoptic meteorology, in particular identifying constraints that must be satisfied by a synoptic classification (Tveito et al, 2016). Any classification should be automated (objective), show physical sense and be straightforward to apply. Different synoptic types should produce different weather conditions on the ground and in cases where the surface and upper air are often decoupled, it is mandatory to include upper-level types (often $500 \mathrm{hPa}$ ).

The first manual attempts to catalogue synoptic types were in the 1940 s and were dependent on human intervention, often involving some degree of subjectivity. Bauer et al (1944) developed a manual classification covering Central Europe, which was improved by Hess and Brezowsky (1952). Pédelaborde (1957) created a manual classification of "weather types" for Paris. Some years later, Lamb (1972) designed a manual synoptic classification for the British Isles based on air flow direction and isobaric curvature. Towards the end of the $20^{\text {th }}$ century, the evolution of computing capabilities allowed the development of objective classifications based on pressure fields. Lund (1963) developed the first objective classification, relating charts through calculation of temporal correlations between grid points of daily sea level pressure charts. Some years later, Jenkinson and Collison (1977) built an objective classification to replicate the Lamb manual classification. Another example of objectivizing a manual classification was James (2017) for the Hess-Brezwosky manual classification (Hess and Brezwosky 1952). More recently, many classifications have been developed based on statistical methods, such as Principal Component Analysis (Von Storch and Zwiers, 1999; Yarnal, 1984; 
Barry and Carleton, 2001), clustering (Valverde et al, 2015), synoptic objective processes (Fernández et al, 2003; Soriano et al, 2006), or machine learning algorithms such as SelfOrganizing Maps (Michaelides, 2001; Michaelides et al, 2007; Nishiyama et al, 2007).

Focusing on the Iberian Peninsula, there have been several examples of manual synoptic classifications. The first was carried out by Albentosa (1973), inspired by the work of Pédelaborde, but applied to Catalonia. Some years later the Clavero and Raso (1979) classification covered the Iberian Peninsula and Balearic Islands. Finally, Martin-Vide (1987) developed a very simple manual synoptic classification for the Iberian Peninsula. Automated synoptic classifications over the Iberian Peninsula have included many based on PCA and cluster analysis (e.g. Romero et al, 1999; Serra et al, 1999, Lemus- Canovas et al, 2019). The most widely used was perhaps that of Esteban et al. (2006) which covers all of Western Europe. The Jenkinson-Collison classification has also been adapted for the Iberian Peninsula (Goodes and Palutikov, 1998; Trigo and DaCamara, 2000; Spellman, 2000; Pepin and Kidd, 2006; Grimalt et al, 2013; Ramos et al., 2011; Ramos et al., 2015; Martin-Vide, 2016). Despite its wide use, types are defined using only surface information and do not take into account the structures aloft, which are crucial in the Mediterranean area (Martín-Vide, 2001). This deficiency is particularly notable for synoptic surface types with airflow coming from the Mediterranean Sea, notably easterly and south-easterly flows, or in situations with a slack pressure gradient (often classed as undetermined pressure gradient). In such cases, very different weather types can result for the same surface synoptic type, depending on the stability above (Miró, 2017).

This paper therefore presents a new synoptic classification for the Western Mediterranean centred on Catalonia (the northeast of Iberian Peninsula) inspired by the Jenkinson and Collison classification (Miró, 2017), but modified taking into account 500hPa patterns. A reduction of the possible number of combined synoptic patterns is achieved through simulating the existing manual classification of Martin-Vide (1991).

Validation of the new classification is performed by assessing its ability to discriminate patterns conducive to cold air pool (CAP) formation in the Cerdanya Valley, located in Catalonia. During nights with clear skies and calm conditions, surface temperatures drop rapidly forming a thermal inversion layer that is also known as a CAP. Several studies have characterized this process in the region (Pepin \& Kidd 2006, Lundquist et al 2008; 
Pagès et al, 2017; Conangla et al, 2018, Miro et al. 2018). Synoptic conditions on days prone to CAP or no-CAP will be classified using the new classification and results compared with those based on the surface Jenkinson-Collision classification alone.

\section{STUDY AREA}

The study area is centred on Catalonia (north-eastern Iberian Peninsula) approximately from $41-43^{\circ} \mathrm{N}$ and $0-3.5^{\circ} \mathrm{E}$. The climate is dominated by the seasonal cycle of midlatitudes and by the temperate westerly jet stream, especially in winter, but sometimes sub-tropical influences appear, especially in summer. Catalonia has complex topography and is surrounded in the east and south by the Mediterranean Sea. The Pyrenees form a boundary in the north and the Ebro Valley in the west (Figure 1). The Cerdanya basin is located in the upper reaches of the river Segre, with an orientation running from eastnortheast to west-southwest (Figure 1). The basin is approximately $45 \mathrm{~km}$ long, $15 \mathrm{~km}$

wide and is flat-bottomed. The valley floor lies at around $1000 \mathrm{~m}$ above sea level and the surrounding peaks are higher than $2000 \mathrm{~m}$. Thus, although wide, the valley also has considerable elevation range. Due to the topographical setting, air masses coming from the Atlantic Ocean (from between south-west and north) are relatively dry due to the upstream protection of high-elevation central Iberia to the south-west and the Pyrenees range to the west and north. Most moisture is imported from the Mediterranean from the east.

The configuration of the Cerdanya basin encourages Cold-Air Pool (CAP) formation since valley narrowing to the south-west makes it difficult for down-valley flow to escape fast enough. Thus the basin, and its wider context, have been studied in terms of thermal inversions and CAP generation in past papers (Pepin and Kidd, 2006; Jimenez and Cuxart, 2014; Pages et al. 2017; Miró et al., 2018).

\section{DATA}

We used ERA-Interim reanalysis (Dee et al. 2006) for constructing and validating the synoptic classification. This was provided by the European Centre for Medium Range Weather Forecasts (ECMWF). Data covers 1979-2017 and the fields used were sea level pressure and geopotential height at $500 \mathrm{hPa}$ at $00 \mathrm{UTC}$. 
To measure temperature profiles, forty HOBO U23-001 sensors (temperature/relative humidity) were installed along the Cerdanya valley and in areas immediately outside the watershed, in several transects (Miró et al., 2018) (Figure 1). Observations were recorded every 30 minutes from July 2012 until July 2017. The accuracy of the temperature sensor is $+/-0.21{ }^{\circ} \mathrm{C}$ and the operating range from $-40{ }^{\circ} \mathrm{C}$ to $70{ }^{\circ} \mathrm{C}$, adequate for local scale temperature monitoring (Whiteman et al., 2000). In mid-latitudes there are large contrasts in radiation regimes between north and south facing slopes and therefore three transects were installed on each aspect (north and south side of Cerdanya). One transect was installed in the adjacent Conflent valley, starting at Fontpedrouse (Figure 1).

\section{METHODOLOGY: SYNOPTIC CLASSIFICATION}

The Jenkinson and Collinson objective classification at the surface was combined with one following a similar scheme applied to geopotential height at $500 \mathrm{hPa}$. As the traditional Jenkinson-Collison classification has 27 types, a simple cross-tabulation will result in $27 * 27$ (i.e. 729 ) possible combinations meaning that a consolidation is necessary. As the synoptic structures at $500 \mathrm{hPa}$ tended to be more clearly defined, several types at $500 \mathrm{hPa}$ could be combined, but this simplification was not enough. We therefore used the manual classification created by Martin-Vide (1991) to consolidate different surface/upper air combinations further.

\subsection{Jenkinson and Collison: surface level $\left(\mathrm{JC}_{\text {sfc }}\right)$}

The Jenkinson-Collison classification is based in calculating approximations of some atmospheric parameters over a simplified grid, that could be of 9 or 16 points. Some authors use the original 16 grid points (Jenkinson and Collison, 1977), but others use a 9 grid point version, developed by El Dessouky and Jenkinson (1975). Rarely are technical reasons given for choosing the exact configuration. Over the Iberian Peninsula, some authors have used a 9 point grid (Grimalt et al, 2013) centred over the Western Mediterranean, while others have used a 16 point grid (Trigo and DaCamara, 2000; Vicente-Serrano \& López-Moreno, 2006) over the Western Iberian Peninsula. It is not easy to compare these schemes directly because each grid type is focused on a different climatic area. Only one paper mentions sensitivity of the Jenkinson-Collison classification to the grid chosen (Demuzere et al, 2009). Working with more grid points reduces the number of unclassified cases, but this work also concluded that it is important 
to choose a resolution related to the typical synoptic structure being examined. Differences between a grid spacing of $10^{\circ}$ and $5^{\circ}$ were not significant in this regard in the above study in terms of discriminating unclassified structures.

In this study therefore, after comparing results using grids of 9 and 16 points and observing slight differences (not shown), the 9 point grid (based on El Dessouky and Jenkinson (1975)) was chosen as better for our area of study and purpose, after comparing case by case with weather charts. Typical synoptic structures in Catalonia and the western Mediterranean are smaller than in the Atlantic and Northern Europe and do not tend to follow the jet stream from west to east, but are often decoupled from the main circulation and stagnate or form in the western Mediterranean. Taking a less extensive 9 point grid therefore has advantages, discriminating between systems related to the upper westerly jet vs those formed due to local influences prevalent in the Mediterranean.

Using values of Sea Level Pressure (SLP) covering Western Europe, a sub grid of $3 \times 3$ points was chosen (Figure 2a). Flow strength (F), flow direction (D) and vorticity (Z) of the airflow are calculated applying the following equations:

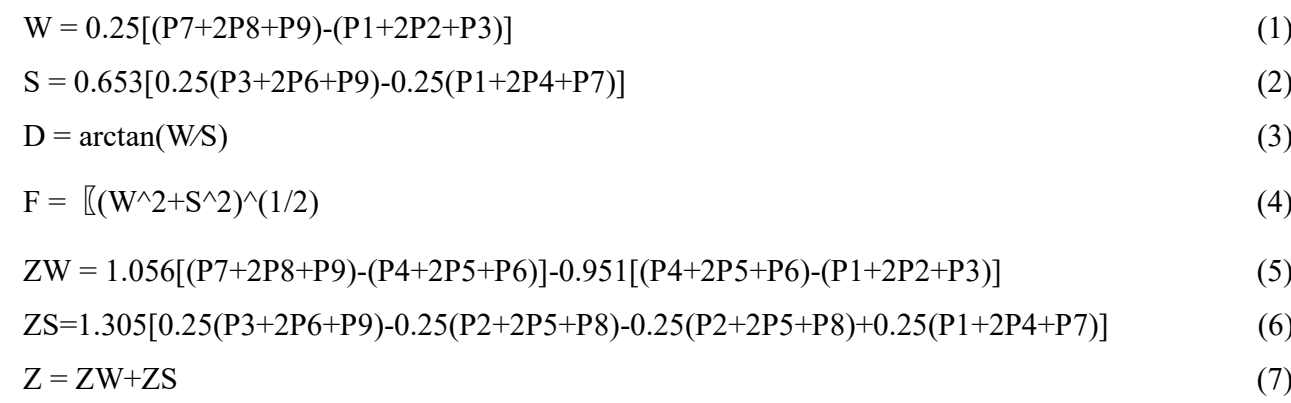

$\mathrm{P} 1$ to $\mathrm{P} 9$ are the pressure values in the points of the $3 \times 3$ grid domain used to calculate the different parameters. In our case the domain is defined by $35^{\circ} \mathrm{N}-45^{\circ} \mathrm{N}$ and $10^{\circ} \mathrm{W}-10^{\circ} \mathrm{E}$ (Figure 2a). The scaling factors that appear in the formulae are dependent on geographical latitude where the grid is centred and number of grid points used (see previous discussion). Therefore, they are slightly different than the original scaling factors given by Jenkinson \& Collison (1977). Based on the values of F, D and Z, the synoptic classification is defined by 4 rules: 
1. If $|\mathrm{Z}|<\mathrm{F}$, the type is pure advective and labelled by the flow direction, one of: $\mathrm{N}$ (North), Northeast (NE), East (E), Southeast (SE), South (S), Southwest (SW), West (W), Northwest (NW)

2. If $|Z|>2 F$, this represents strong vorticity and the type is pure cyclonic (C) if $Z>0$ or pure anticyclonic (A) if $\mathrm{Z}<0$.

3. If $\mathrm{F}<|\mathrm{Z}|<2 \mathrm{~F}$ then flow direction is combined with vorticity in a hybrid type, one of: $\mathrm{CN}$, CNE, CE, CSE, CS, CSW, CW, CNW, AN, ANE, AE, ASE, AS, ASW, AW and ANW.

4. If $\mathrm{F}<6$ and $|\mathrm{Z}|<6$ the resultant type is called unclassified (U).

One of 27 possible synoptic types can be derived for each sea-level surface pressure field.

\subsection{Jenkinson and Collison: $500 \mathrm{hPa}\left(\mathrm{JC}_{500}\right)$}

To classify upper-air pressure patterns, a similar methodology was applied using $500 \mathrm{hPa}$ geopotential heights, but the grid was displaced five degrees to the west (Figure 2b). At $500 \mathrm{hPa}$ structures tend to move from west to east and often it is the approaching upper air pattern which controls the atmospheric (in)stability. The equations to calculate F, D and $\mathrm{Z}$ remain unchanged.

The most critical information that the $500 \mathrm{hPa}$ level provides is the division into stable (ridge) and unstable (trough) types. The direction of the upper air flux is not that critical, and often has a westerly component. Thus, as a first attempt to simplify types at $500 \mathrm{hPa}$ we considered five types: a) cyclone, b) trough: merging all the cyclonic hybrid types, c) anticyclone, d) ridge: merging all the anticyclonic hybrid types, and e) pure advective types. The thresholds which separate pure cyclonic/anticyclonic types from hybrid types, and in turn hybrid types from pure advective types, needed to be changed with respect to those used at the surface. Indeed as values of $\mathrm{F}$ and $\mathrm{Z}$ do not show any clustering, the thresholds chosen can be seen as arbitrary values imposed on a smooth distribution (Goodess and Palutikoff, 1998). The structures that appear at $500 \mathrm{hPa}$ in general are different to those at the surface so it is perfectly reasonable to use modified thresholds in the upper air to discriminate between pure anticyclones and ridges for example. We therefore used the thresholds below:

1. If $\mathrm{Z}>0$ and $|\mathrm{Z}|<(1 / 3)^{*} \mathrm{~F}$ or $\mathrm{Z}<0$ and $|\mathrm{Z}|<(4 / 3)^{*} \mathrm{~F}$ the cases are considered as pure advection (N, NE, E, SE, S, SW, W, NW). 
2. If $|Z|>6 F$, a cyclone $(Z>0)$ or anticyclone $(Z<0)$ was defined.

3. If $(1 / 3)^{*} \mathrm{~F}<|\mathrm{Z}|<6 \mathrm{~F}$ and $\mathrm{Z}>0$ (cyclonic) a trough above was defined (N, NE, E, SE, S, SW, W, NW).

4. If $(4 / 3) * \mathrm{~F}<|\mathrm{Z}|<6 \mathrm{~F}$ and $\mathrm{Z}<0$ (anti-cyclonic) a ridge above was defined (N, NE, E, SE, S, SW, W, NW).

5. If $\mathrm{F}<6$ and $|\mathrm{Z}|<6$ the type is unclassified (U).

In the upper air, curvature tends to increase more than flow strength and thus the threshold for discriminating between pure cyclonic/anticyclonic and hybrid classifications was increased from 2 (at the surface) to 6. This new threshold was obtained after sensitivity analysis with alternative thresholds. The thresholds between hybrid and pure advective cases were also changed, but in a different sense depending whether the isohypses displayed anticyclonic or cyclonic curvature.

In summer, even when there is a weak trough aloft, the presence of strong heating or the uplift created by a mountain barrier can produce storms and rainy weather. To catch this, the threshold discriminating between a trough and pure advection was lowered to $1 / 3$, lower than the surface Jenkinson-Collison classification threshold (1), enabling weak troughs to be captured. On the other hand, the threshold separating a ridge from pure advection was fixed at 4/3, larger than the original Jenkinson Collison threshold (1). This later change helps to discriminate amongst stable situations, mainly in winter, in which in some cases despite the anticyclonic curvature the presence of strong wind aloft means it should be considered as advection.

Because there are many possible combinations of surface and upper air types, the next step was to combine both classifications to replicate the manual classification of MartinVide (1991).

\subsection{The new classification proposed.}

In a similar way to the work of Jones et al. (1993), which reproduced Lamb's manual classification with the objective Jenkinson-Collison scheme, our new classification is tuned to provide an objective version of Martin-Vide (1987, 1991). Martin-Vide's manual classification was designed for the Iberian Peninsula and Balearic Islands, based on both surface and $500 \mathrm{hPa}$ configurations. It identifies 16 synoptic types (Table 1), each of 
which was now compared with the combined types we obtained from automatic classification at the two levels. The contingency table (Table 2) shows that for each surface Jenkinson-Collison type, the corresponding types at $500 \mathrm{hPa}$ are usually limited and we can develop some rules to transfer our surface/upper air combination to the Martin-Vide equivalent classification:

- Surface types NE,N,NW,W,SW and S (both pure and hybrid) usually have a similar flow direction at $500 \mathrm{hPa}$ and form Martin-Vide types 5,4,3,1,9 and 8 respectively. For example the surface northerly types (pure and hybrid) usually correspond to types N, NW (pure and hybrid) at $500 \mathrm{hPa}$ which corresponds with "North Advection" (TYPE04).

- The surface types E, SE are associated with more confused patterns in the upper air. As well as expected related types (upper level easterly and south-easterly flow (TYPE06)), they also occur with hybrid and closed cyclonic types aloft (TYPE07). This corresponds to "East Advection" and "East Advection with cut-off above" respectively.

- For the Anticyclonic types at the surface there are two common corresponding structures aloft; a closed anticyclone (TYPE15), and westerly winds (hybrid or pure) (TYPE02) which relates to the Martin-Vide types: "Anticyclone" and "Anticyclonic Western Advection" respectively. More rarely a cyclone appears above which corresponds with “Thermal Anticyclone” (TYPE16).

- Surface cyclones are often also cyclonic circulation (hybrid or pure) at $500 \mathrm{hPa}$ (TYPE12) but there are also pure advection types (mainly West and South West) (TYPE13). These are the "Cyclone" and "Thermal low" of Martin-Vide's types respectively.

- Finally if there is an unclassified type at surface, the upper air related types are usually pure and hybrid W/SW advection. An unclassified situation with cyclonic circulation above is related to instability and related to the "Trough" type of Martin-Vide (TYPE10). If the circulation is related to upper cyclonic SW advection in upper levels the overall classification is "Upper cyclone in SW Peninsula Ibèrica" (TYPE11). The remainder usually have westerly advection at upper levels and are considered as "Undetermined pressure gradient" (TYPE14).

Following the above rules we automatically assigned our surface/upper air combination to one of Martin-Vide's 16 manual classifications (Table 3). However, a detailed comparison between types obtained using these rules and the manual Martin-Vide classification revealed some mismatches, meaning that some fine-tuning was necessary: 
- Surface AW and CW types were associated in a first attempt to TYPE03, but looking in more detail they were always reassigned to TYPE02 in case of AW and TYPE10 in case CW.

- Martin-Vide's "Thermal Low" (TYPE 13) has a surface cyclone but stable (pure or hybrid) or advective types above and forms mainly in summer. This situation is difficult to characterize with the automatic classification, because in winter, low pressure can form in the Gulf of Genoa after a frontal passage, which is also associated with stable conditions (mainly hybrid) and/or pure advective types aloft. These winter situations also get classified as "Thermal Low" under the rules. As TYPE13 represented only $6 \%$ of cases, each example was examined in detail and was discriminated as follows: Upper flow from N, NW and NE (hybrid or pure) was reassigned as TYPE12, and upper flow with directions W, SW, SE and E (hybrid or pure) was kept assigned as TYPE13.

To prove that the combined surface/upper level automatic classification and Martin Vide's manual one are statistically comparable, a Chi-squared test was applied, using 10 years of data from September 1957 until August 1967. This corroborated that both classifications could be considered similar. They were shown to coincide in $84 \%$ of cases.

For our study area some types occurred very rarely and to avoid small numbers some types were combined: TYPE11 was rare $(1.7 \%$ of cases $)$ and tended to be similar to TYPE09 (also fairly infrequent at 5.1\%) and thus both were combined. Because some TYPE13 situations had been reclassified as TYPE12, it was also infrequent (2.3\%). Due to similarity with TYPE14 (15.1\% of cases), both types were combined. Finally, the anticyclonic types TYPE15 and TYPE16 were combined because TYPE16 appeared only in very few cases (only $0.4 \%$ ). Applying these changes reduced the number of patterns to 13. To avoid confusion with the original types we refer to the final types as TYPE_s_NN where $\mathrm{NN}$ is the number (see Table 4).

\section{Results}

Composites of each synoptic type were created and the charts obtained are as expected for each manual type of the Martin-Vide's classification (Figure 3). Some types are more common in winter, including those associated with deep Atlantic cyclones (TYPE_s_01, 
TYPE_s_03, TYPE_s_04) or pure anticyclonic situations (TYPE_s_13). On the other hand, undefined situations at the surface are more typical in summer (TYPE_s_10 and TYPE_s_12) (Figure 3).

A validation of the classification using CAP and no-CAP days was performed to examine its success at discriminating such events. Using the EOF methodology proposed by Miró et al. (2017), each day from July 2012-July $2017(n=1826)$ was classified as prone to CAP or to no-CAP using the HOBO data. Figure 4 shows that CAP days occur mainly under anticyclonic types, especially TYPE_s_02 and TYPE_s_13, as expected. Such days often have calm winds and clear skies. CAP is also frequent with TYPE_s_12, which although not anticyclonic, is characterised by slack isobars, lack of wind and often clear skies, especially in winter. TYPE_s_09 which corresponds to SW advection is also prone to develop CAP. These results are compatible with those of Miró et al (2018).

Days prone to no-CAP are expected to be dominated by situations in which winds are strong and skies are usually cloudy. TYPE_s_11 is common, and corresponds to a cyclone, usually forming in the western Mediterranean. This can form as the upper level westerly flow interacts with the Pyrenees, or as a synoptic low steered by the jet stream (Trigo et al, 2002). Types related to winds coming the north or north-west (TYPE_s_03, TYPE_s_04, TYPE_s_05) and less frequently from the west (TYPE_s_01) are also prone to no-CAP. These are also consistent with the types obtained in Miró et al (2018).

\section{Discussion}

Comparing our classification with existing objective synoptic classifications oriented to the Mediterranean (Serra et al, 1999; Fernández et al, 2003; Esteban et al, 2006), many of the basic types (anticyclone, cyclone, north-westerly advection, easterly advecion) are similar. The mentioned classifications are based in statistical and mathematical approach and some synoptic types appear as transitional types, which in general are not synoptically relevant. The main advantage of using a classification with thresholds is that discriminates better having all the types synoptically significant.

Comparing our new combined classification with the classical surface-based JenkinsonCollison, the main advantage is that it allows differentiation within the unclassified type, 
common in the latitudes of the Iberian Peninsula, especially in summer when the general flow is weak (Spellman, 2000). To illustrate this, we re-run the CAP analysis using the surface classification alone, see Figure 5. The main types prone to CAP events are A and $\mathrm{U}$ (Figure 5a) which means that despite anticyclonic days being dominant, there is a large number of CAP days that are unclassified. An additional $500 \mathrm{hPa}$ classification is required to discriminate stable from unstable cases. In addition, days prone to no-CAP are mainly C (cyclone) (Figure 5b), or hybrid flows coming from the N, NE, NW, in-line with the results obtained with the new classification.

In contrast to the surface classification, the new classification is more precise at determining the necessary types for CAP, as well as reducing the number of unclassified situations which were frequent when using surface type alone. For our new classification, for nearly all synoptic types, either CAP or no-CAP is dominant and there are no types which have roughly 50:50 distribution of CAP/no CAP occurrences. This demonstrates that the new classification is extremely efficient at differentiating between CAP and noCAP synoptic situations.

Previous work has shown a strong advantage in using the combined classification to improve forecasts of precipitation events where similar types at the surface (easterly advection or undetermined pressure gradient situations) could produce very different results dependent on the upper air flow structures (Miró, 2017). This work has shown that the classification also has advantages over a surface based classification at predicting CAP events in eastern Cerdanya. Most notably it is able to discriminate between the large number of unclassified days based on a surface classification alone which may or may not lead to CAP.

\section{Conclusions}

The simple classification developed in this paper has only 13 types, each one with a clear synoptic configuration, which is very useful for forecasters. Reducing the number of types gives clarity and is advantageous because there will be more case studies available for each type. Despite this simplicity, this classification has the advantage of separating broadly similar types at the surface, but with upper air differences, that tend to have 
different consequences for both precipitation forecasting and for CAP and atmospheric stability.

This classification therefore provides a straightforward tool for daily use by forecasters as a first step for developing a weather forecast (Snellman, 1982; 1982; Lanicci, 2003; Athar and Sara, 2014). This classification could also be used for downscaling future climate forecasts, in particular studying the temporal evolution of the relative frequencies of various synoptic types and thus the potential influence of circulation changes on climate change in contrasting micro-environments. For example, understanding the changing frequency of CAP events in the Cerdanya Valley by relating cold pool events to changing synoptic patterns would be a useful area for further research.

Acknowlegments: This work was partially funded by grants from the Spanish government CGL2015-65627-C3-1-R (AEI/FEDER, UE). 


\section{References}

Albentosa, L.M., (1973). Los climas de Cataluña. Estudio de Climatología dinámica (PhD Thesis). Summary published for the University of Barcelona in 1975. $32 \mathrm{pp}$.

Athar, H., and Sara, A. (2014). Weather forecast skill comparisons at a location in the Midwest United States. Meteorological Applications, 21(4), 930-939

Barry, R. G. and Carleton, A. M. (2001). Synoptic and dynamic climatology. Routledge: London.. $620 \mathrm{pp}$.

Baur F, Hess P and Nagel H. (1944). Kalender der Grosswetterlagen Europas 1881-1939. DWD: Bad Homburg. Germany. 35 pp.

Clavero, P. and Raso, J. (1979). Catálogo de tipos sinópticos para un estudio climático del Este de la Península Ibérica y Baleares. Aportacions en homenatge del geògraf Salvador Llobet, 6386, Departament de Geografia., Universitat de. Barcelona.

Conangla, L., Cuxart, J., Jiménez, M. A., Martínez-Villagrasa, D., Miró, J. R., Tabarelli, D., and Zardi, D. (2018). Cold-air pool evolution in a wide Pyrenean valley. International Journal of Climatology, 38(6), 2852-2865.

Dee, D. P., Uppala, S. M., Simmons, A. J., Berrisford, P. , Poli, P., Kobayashi, S. , Andrae, U. , Balmaseda, M. A., Balsamo, G. , Bauer, P. , Bechtold, P., Beljaars, A. C., van de Berg, L., Bidlot, J. , Bormann, N. , Delsol, C., Dragani, R. , Fuentes, M., Geer, A. J., Haimberger, L., Healy, S. B., Hersbach, H. , Hólm, E. V., Isaksen, L., Kållberg, P. , Köhler, M. , Matricardi, M. , McNally, A. P., Monge-Sanz, B. M., Morcrette, J. , Park, B. , Peubey, C. , de Rosnay, P. , Tavolato, C. , Thépaut, J. and Vitart, F. (2011). The ERA-Interim reanalysis: configuration and performance of the data assimilation system. Quarterly Journal of the Royal Meteorological Society, 137: 553597. https://apps.ecmwf.int/datasets/data/era40-daily/levtype=sfc/

Demuzere, M., Werner, M., Van Lipzig, N. P. M., and Roeckner, E. (2009). An analysis of present and future ECHAM5 pressure fields using a classification of circulation patterns. International Journal of Climatology, 29(12), 1796-1810.

El Dessouky, T. M. and Jenkinson, A. F. (1975). An objective daily catalogue of surface pressure, flow and vorticity indices for Egypt and its use in monthly rainfall forecasting. Meteorological Research Bulleting, Egypt, 11, 1-25. 
Esteban P., Martín-Víde, J. and Mases, M. (2006). Daily atmospheric circulation catalogue for Western Europe using multivariate techniques. International Journal of Climatology, 26, 15011515.

Fernández, A.J., Martín-Vide, J., Díaz, Y.A. and Mestre, A. (2003). Aplicación de los procesos sinópticos objetivos a la Península Ibérica en otoño. Investigaciones Geográficas, 31, 37-65, Alicante, Universidad de Alicante.

Goodess, C. M. and Palutikof, J. P. (1998). Development of daily rainfall scenarios for southeast Spain using a circulation-type approach to downscaling. International Journal of Climatolology, 18: 1051-1083.

Grimalt, M., Tomàs, M., Alomar, G., Martín-Vide, J. and Moreno-García, M. C. (2013). Determination of the Jenkinson and Collison's weather types for the western Mediterranean basin over the 1948-2009 period. Temporal analysis. Atmósfera 26(1), 75-94.

Hess P, and Brezowsky H. (1952). Katalog der Grosswetterlagen Europas. Berichte des Deutschen Wetterdienstes in der US-Zone, 33, 39 pp.

James P.M. (2007). An objective classification for Hess and Brezowsky Grosswetterlagen over Europe. Theoretical and Applied Climatology., 88, 17-42.

Jenkinson A.F., and Collison, B.P. (1977). An initial climatology of gales over the North Sea. Synoptic Climatololgy Branch Memorandum, 62, Meteorological Office, London, UK. 18 pp.

Jiménez, M. A., and Cuxart, J. (2014). A study of the nocturnal flows generated in the north side of the Pyrenees. Atmospheric research, 145, 244-254.

Jones, P.D., Hulme, M. and Briffa, K.R. (1993). A comparison of Lamb circulation types with an objective classification scheme. International Journal of Climatology, 13, 655-663.

Lamb, H.H. (1972): British Isles Weather types and a register of daily sequence of circulation patterns, 1861-1971. Geophysical Memoirs 116, HMSO, London, 85 pp.

Lanicci, J. M. (2012). Using a business process model as a central organizing construct for an undergraduate weather forecasting course. Bulletin of the American Meteorological Society, 93(5), 697-709. 
Lemus-Canovas, M., Lopez-Bustins, J. A., Trapero, L., and Martin-Vide, J. (2019). Combining circulation weather types and daily precipitation modelling to derive climatic precipitation regions in the Pyrenees. Atmospheric research, 220, 181-193.

Lund, I. A. (1963). Map-pattern classification by statistical methods. Journal of Applied Meteorology, 2(1), 56-65.

Lundquist, J. D., Pepin, N., and Rochford, C. (2008). Automated algorithm for mapping regions of cold-air pooling in complex terrain. Journal of Geophysical Research: Atmospheres, 113,D22107.

Martín-Vide, J. (1987). Característiques climatològiques de la precipitació en la franja costera mediterrània de la Península Ibèrica. Tesi Doctoral. Institut Cartogràfic de Catalunya, Generalitat de Catalunya, Barcelona. 245 pp

Martín-Vide, J. (1991). Mapas del tiempo: fundamentos, interpretación e imágenes de satélite. Oikos-tau. Barcelona:. 170 pp

Martín-Vide, J. (2001): Limitations of an objective weather-typing system for the Iberian peninsula. Weather, 56, 7, 248-250, Royal Meteorological Society.

Martín Vide, J., Moreno García, M. C., Artola, V. M., and Cordobilla, M. J. (2016). Los tipos sinópticos de Jenkinson and Collison y la intensidad de la isla de calor barcelonesa. Clima, sociedad, riesgos y ordenación del territorio, 565-574.

Michaelides, S. C., Liassidou, F. and Schizas, C. N. (2007). Synoptic classification and establishment of analogues with artificial neural networks. Fog and Boundary Layer Clouds: Fog Visibility and Forecasting, 1347-1364. Birkhäuser Basel.

Michaelides, S. C., Pattichis, C. S. and Kleovoulou, G. (2001). Classification of rainfall variability by using artificial neural networks. International Journal of Climatology, 21(11), 1401-1414.

Miró Cubells, J. R (2017). Patrons mesoscalars de precipitació a Catalunya (PhD dissertation, Universitat de Barcelona). 229 pp.

Miró, J. R., Peña, J. C., Pepin, N., Sairouni, A. and Aran, M. (2018). Key features of cold-air pool episodes in the northeast of the Iberian Peninsula (Cerdanya, eastern Pyrenees). International Journal of Climatology, 38(3), 1105-1115. 
Nishiyama, K., Endo, S., Jinno, K., Uvo, C. B., Olsson, J., and Berndtsson, R. (2007). Identification of typical synoptic patterns causing heavy rainfall in the rainy season in Japan by a self-organizing map. Atmospheric research, 83(2-4), 185-200.

Pagès, M., Pepin, N., and Miró, J. R. (2017). Measurement and modelling of temperature cold pools in the Cerdanya valley (Pyrenees), Spain. Meteorological Applications, 24(2), 290-302.

Pédelaborde, R (1957): Le climat du bassin parisien. Editorial Genin. Paris. 461 pp.

Pepin, N.and Kidd, D. (2006). Spatial temperature variation in the Eastern Pyrenees. Weather, 61(11), 300-310.

Philipp, A., Bartholy, J., Beck, C., Erpicum, M., Esteban, P., Fettweis, X., Huth, R., James, P., Jourdain, S., Kreienkamp, F., Krennert, T., Lykoudis, S., Michalides, S.C.; Pianko-Kluczynska, K., Post, P., Rasilla Álvarez, D., Schiemann, Spekat, A. and Tymvios, F.S. (2010). Cost733catA database of weather and circulation type classifications. Physics and Chemistry of the Earth, Parts A/B/C, 35(9), 360-373.

Ramos, A. M., Ramos, R., Sousa, P., Trigo, R. M., Janeira, M., and Prior, V. (2011). Cloud to ground lightning activity over Portugal and its association with circulation weather types. Atmospheric Research, 101(1-2), 84-101.

Ramos, A. M., Cortesi, N. and Trigo, R. M. (2014). Circulation weather types and spatial variability of daily precipitation in the Iberian Peninsula. Frontiers in Earth Science, 2, 25.

Romem, M., Ziv, B., and Saaroni, H. (2007). Scenarios in the development of Mediterranean cyclones. Advances in Geosciences, 12, 59-65.

Romero, R., Sumner, G., Ramis, C.and Genovés, A., (1999). A classification of the atmospheric circulation patterns producing significant daily rainfall in the Spanish Mediterranean area. International Journal of Climatolology, 19, 765-785.

Serra, C., Fernández-Mills, G., Periago, M.C. and Lana, X. (1999). Winter synoptic weather types in Catalonia (NE Spain) and their linkage with minimum temperature anomalies. International Journal of Climatology 19, 15, 1675-1695

Snellman, L. W., (1982). Impact of AFOS on Operational Forecasting, Preprints, Ninth Conference on Weather Forecasting and Analysis, Seattle, WA, American Meteorological Society, 13-16. 
Soriano C., Fernández A. and Martín-Vide,J.(2006) Objective synoptic classification combined with high resolution meteorological models for wind mesoscale studies. Meteorology and Atmospheric Physics, vol. 91, 165-181.

Spellman G. (2000) The application of an objective weather-typing system to the Iberian peninsula. Weather 55: 375-385.

Storch H von and Zwiers FW (1999) Statistical analysis in climate research. Cambridge University Press, $494 \mathrm{pp}$.

Trigo, R.M. and DaCamara, C.C., (2000) Circulation Weather Types and their Influence on the Precipitation Regime in Portugal, International Journal of Climatology 20 (13), 1559-1581

Trigo, I. F., Bigg, G. R., and Davies, T. D. (2002). Climatology of cyclogenesis mechanisms in the Mediterranean. Monthly Weather Review, 130(3), 549-569.

Tveito, OE, Huth, R., Philipp, A., Post, P., Pasqui, M, Esteban, P., Beck, C., Demuzere, M. and Prudhomme, C. (2016): COST Action 733 Harmonization and Application of Weather Type Classifications for European Regions. Final Scientific Report, 352 pp

Valverde, V., Pay, M. T., and Baldasano, J. M. (2015). Circulation-type classification derived on a climatic basis to study air quality dynamics over the Iberian Peninsula. International Journal of Climatology, 35(10), 2877-2897.

Vicente-Serrano, S. M., and López-Moreno, J. I. (2006). The influence of atmospheric circulation at different spatial scales on winter drought variability through a semi-arid climatic gradient in northeast Spain. International Journal of Climatology, 26(11), 1427-1453.

Whiteman CD, Hubbe JM and Shaw WJ. (2000). Evaluation of an inexpensive temperature datalogger for meteorological applications. Journal of Atmospheric and Oceanic Technology 17: 77- 81.

Yarnal, B. (1984): A procedure for the classification of synoptic weather maps from gridded atmospheric pressure surface data. Computers and Geosciences,10(4), 397-41 
Tables

\begin{tabular}{|c|c|}
\hline Martin-Vide manual classification & Description \\
\hline West advection & $\begin{array}{l}\text { The isobars at the surface and the isohypses at } \\
500 \mathrm{hPa} \text { produce westerly winds. }\end{array}$ \\
\hline Anticyclonic western advection & $\begin{array}{l}\text { Anticyclone at the surface and isohypse } \\
\text { configuration at } 500 \mathrm{hPa} \text { disposed to produce } \\
\text { westerly winds }\end{array}$ \\
\hline Northwest advection & $\begin{array}{l}\text { Both surface isobars and isohypses at } 500 \mathrm{hPa} \\
\text { produce north-westerly winds }\end{array}$ \\
\hline North advection & $\begin{array}{l}\text { Both surface isobars and isohypses at } 500 \mathrm{hPa} \\
\text { produce northerly winds }\end{array}$ \\
\hline Northeast advection & $\begin{array}{l}\text { Both surface isobars and isohypses at } 500 \mathrm{hPa} \\
\text { produce north-easterly winds }\end{array}$ \\
\hline East advection & $\begin{array}{l}\text { Surface isobars produce easterly winds while at } \\
500 \mathrm{hPa} \text { the isohypses relate to stability or } \\
\text { easterly advection }\end{array}$ \\
\hline East Advection with instability above & $\begin{array}{l}\text { Surface isobars produce easterly winds while } \\
\text { at } 500 \mathrm{hPa} \text { there is instability (cyclone or } \\
\text { trough). }\end{array}$ \\
\hline South advection & $\begin{array}{l}\text { Both surface isobars and isohypses at } 500 \mathrm{hPa} \\
\text { produce southerly winds }\end{array}$ \\
\hline Southwest advection & $\begin{array}{l}\text { Both surface isobars and isohypses at } 500 \mathrm{hPa} \\
\text { produce south-westerly winds }\end{array}$ \\
\hline Upper cyclone in SW Iberian Peninsula & $\begin{array}{l}\text { Cyclone above the Southwest of Iberian } \\
\text { Peninsula coupled with an undefined situation } \\
\text { at the surface. }\end{array}$ \\
\hline Trough & $\begin{array}{l}\text { A trough crossing the Iberian Peninsula from } \\
\text { West to East with an undefined situation at } \\
\text { surface }\end{array}$ \\
\hline Low or Cyclone & A cyclone at $500 \mathrm{hPa}$ and at the Surface \\
\hline Thermal Low & $\begin{array}{l}\text { A shallow cyclone at the surface which } \\
\text { disappears with height appearing an } \\
\text { unclassified situation at } 500 \mathrm{hPa} \text {. More typical } \\
\text { in summer months }\end{array}$ \\
\hline Undetermined pressure gradient & $\begin{array}{l}\text { Thereis no welldefined isobaric configuration } \\
\text { at the surface (often a col or undetermined } \\
\text { pressure gradient) and at } 500 \mathrm{hPa} \text { there is a } \\
\text { ridge or undefined situation }\end{array}$ \\
\hline Anticyclone & $\begin{array}{l}\text { An anticyclone appears both at surface and at } \\
500 \mathrm{hPa} \text {. }\end{array}$ \\
\hline Thermal anticyclone & $\begin{array}{l}\text { Over Central Europe there is cold air which } \\
\text { produces surface high pressurebut this } \\
\text { disappears with height (analagous to thermal } \\
\text { low). }\end{array}$ \\
\hline
\end{tabular}

Table 1. Types of Martin-Vide's manual classification (left) and a description of the related surface and $500 \mathrm{hPa}$ patterns expected for each type. 


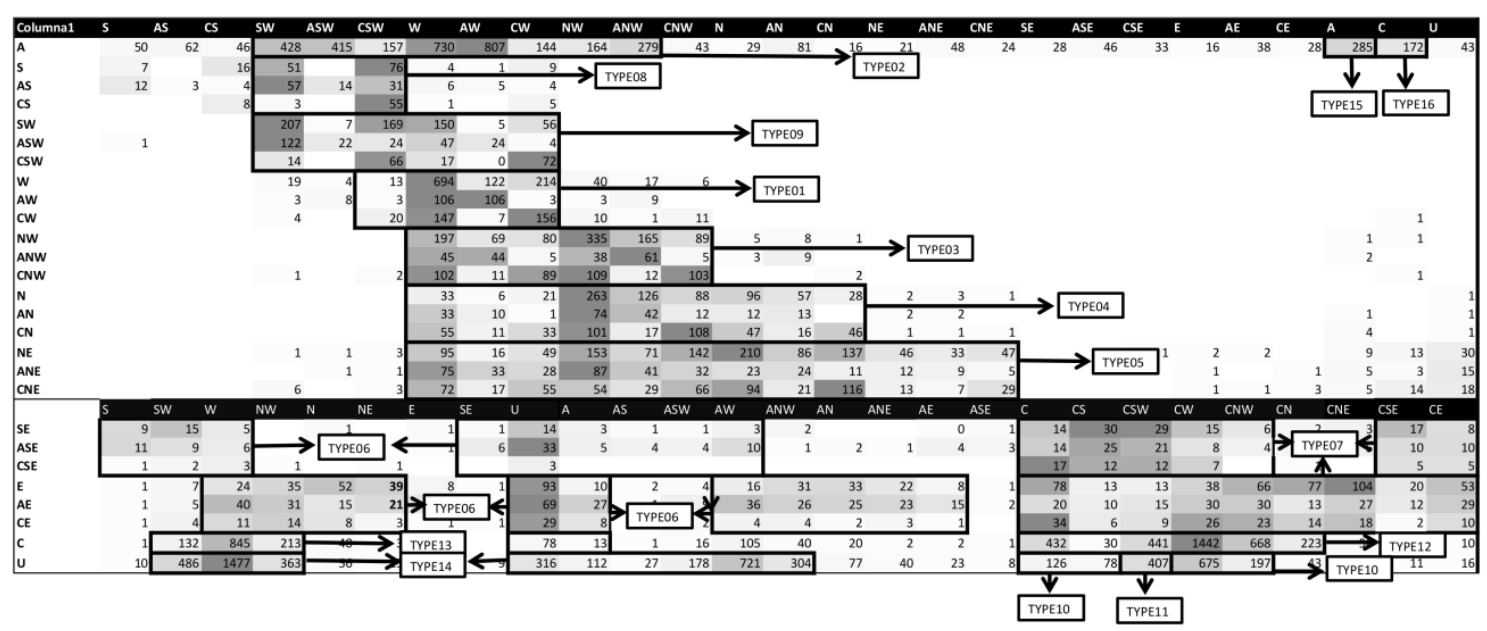

Table 2. Contingency table counting coincident occurrences for every synoptic type for the Jenkinson and Collison classifications at the surface (rows) and $500 \mathrm{hPa}$ (columns). This is split in two parts in order to better show how types are clustered. 


\begin{tabular}{|c|c|c|}
\hline JiC sfe & JiC 500 hPa & New classification \\
\hline \multirow[t]{9}{*}{ A } & Anticyclone or Unclassified & TYPE15 \\
\hline & Ridge (SW,W,NW) & TYPE01 \\
\hline & Ridge (S,SE,E,NE,N) & TYPE15 \\
\hline & Cyclone & TYPE16 \\
\hline & Trough (SW,W,NW) & TYPE01 \\
\hline & Trough $(\mathrm{N}, \mathrm{NE})$ & TYPE16 \\
\hline & Trough ( S,SE,E) & TYPE15 \\
\hline & Pure Advection(S,SE,E,NE,N) & TYPE15 \\
\hline & Pure Advection (SW,W,NW) & TYPE01 \\
\hline \multirow[t]{2}{*}{$\mathrm{AE} / \mathrm{ASE}$} & Any type except (Cyclone or Trough) & TYPE06 \\
\hline & Cyclone or Trough & TYPE07 \\
\hline AS & Any type & TYPE08 \\
\hline ASW & Any type & TYPE09 \\
\hline $\mathrm{AW}$ & Any type & TYPE01 \\
\hline ANW & Any type & TYPE03 \\
\hline $\mathrm{AN}$ & Any type & TYPE04 \\
\hline ANE & Any type & TYPE05 \\
\hline \multirow[t]{6}{*}{$\mathrm{C}$} & Anticyclone or Unclassified & TYPE13 \\
\hline & Pure Advection (W,SW,SE,E) & TYPE13 \\
\hline & Pure Advection (NE,N,NW) & TYPE12 \\
\hline & Ridge (W,SW,SE,E) & TYPE13 \\
\hline & Ridge (NE,N,NW) & TYPE12 \\
\hline & Cyclone or Trough & TYPE12 \\
\hline \multirow[t]{2}{*}{$\mathrm{CE} / \mathrm{CSE}$} & Any type except (Cyclone or Trough) & TYPE06 \\
\hline & Cyclone or Trough & TYPE07 \\
\hline $\mathrm{CS}$ & Any type & TYPE08 \\
\hline CSW & Any type & TYPE09 \\
\hline \multirow[t]{2}{*}{$\mathrm{CW}$} & Any type except (Cyclone or Trough) & TYPE02 \\
\hline & Cyclone or Trough & TYPE10 \\
\hline $\mathrm{CNW}$ & Any type & TYPE03 \\
\hline $\mathrm{CN}$ & Any type & TYPE04 \\
\hline CNE & Any type & TYPE05 \\
\hline \multirow[t]{3}{*}{$\mathrm{E} / \mathrm{SE}$} & Anticyclone or Ridge & TYPE06 \\
\hline & Cyclone or Through & TYPE07 \\
\hline & Pure advection or Unclassified & TYPE06 \\
\hline S & Any type & TYPE08 \\
\hline SW & Any type & TYPE09 \\
\hline W & Any type & TYPE02 \\
\hline NW & Any type & TYPE03 \\
\hline $\mathrm{N}$ & Any type & TYPE04 \\
\hline $\mathrm{NE}$ & Any type & TYPE05 \\
\hline \multirow[t]{4}{*}{$\mathrm{U}$} & Anticyclone + Ridge & TYPE14 \\
\hline & Cyclone or Trough (E,NE,N,NW,W) & TYPE10 \\
\hline & Trough $(\mathrm{S}, \mathrm{SW}, \mathrm{SE})$ & TYPE11 \\
\hline & Unclassified & TYPE14 \\
\hline
\end{tabular}

Table 3. The mapping of combined Jenkinson and Collison types onto Martin Vide's manual classification. The first column shows surface, and second column $500 \mathrm{hPa}$, Jenkinson and Collison types. The third column represents the new classification type obtained combining columns one and two. 


\begin{tabular}{|l|l|}
\hline \multicolumn{1}{|c|}{ New classification } & Description \\
\hline TYPE_s_01 & West advection \\
\hline TYPE_s_02 & Anticyclonic western advection \\
\hline TYPE_s_03 & Northwest advection \\
\hline TYPE_s_04 & North advection \\
\hline TYPE_s_05 & Northeast advection \\
\hline TYPE_s_06 & East advection \\
\hline TYPE_s_07 & East Advection with cut-off low above \\
\hline TYPE_s_08 & South advection \\
\hline TYPE_s_09 & Southwest advection \\
\hline TYPE_s_10 & Trough \\
\hline TYPE_s_11 & Low or Cyclone \\
\hline TYPE_s_12 & $\begin{array}{l}\text { Shallow Cyclone or Undetermined } \\
\text { pressure gradient }\end{array}$ \\
\hline TYPE_s_13 & Anticyclone \\
\hline
\end{tabular}

Table 4. The new simplified synoptic classification with short names (left column) and a brief description (right column). 


\section{Figures}

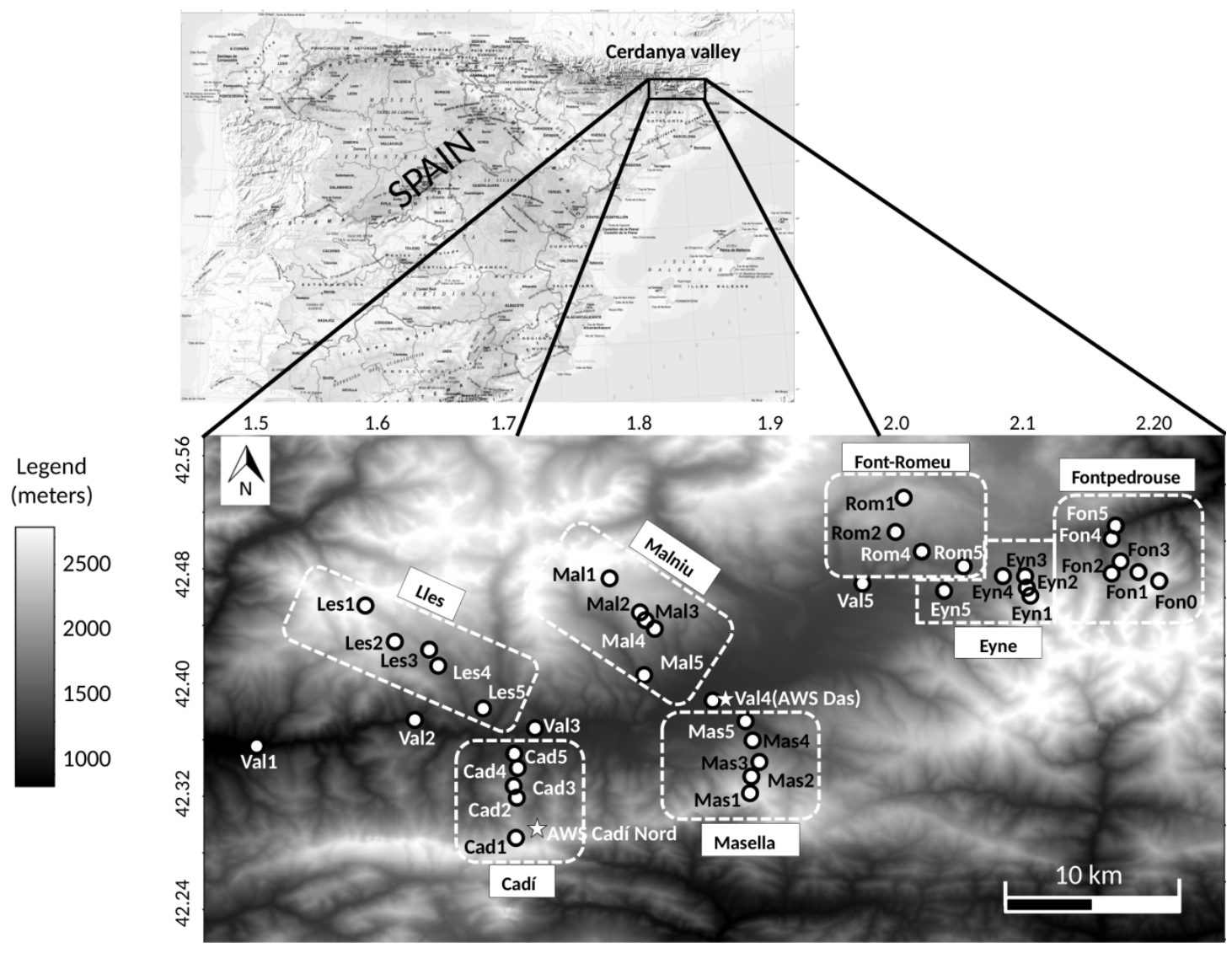

Figure 1. Location of the Cerdanya valley in the context of Catalonia and the north-east Iberian peninsula. The lower panel shows a detailed view of the Cerdanya valley and sensor locations.
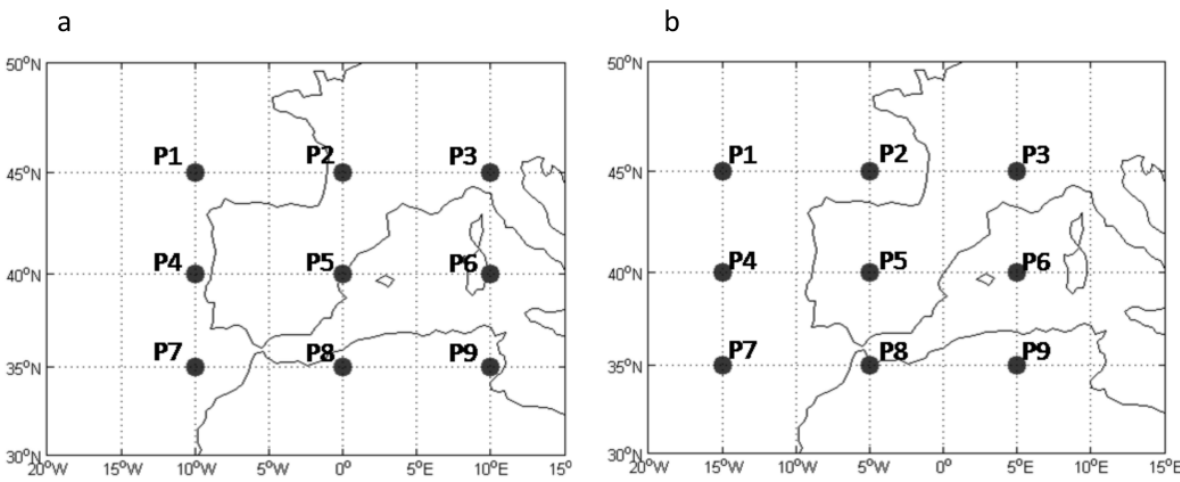

Figure 2. Grids used to calculate Jenkinson and Collision at a) surface and b) $500 \mathrm{hPa}$. 


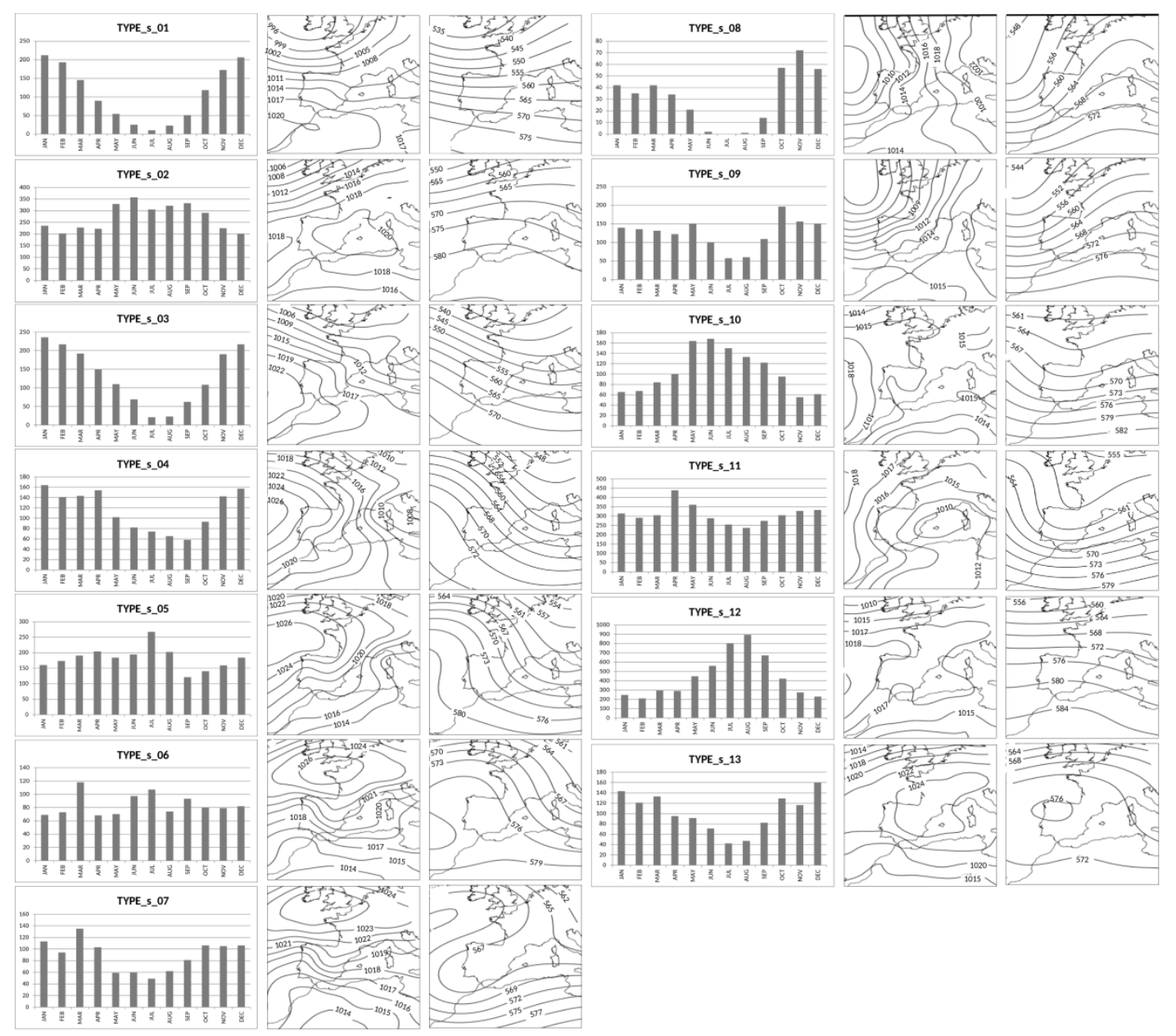

Figure 3. Monthly frequencies for each of the 13 final synoptic types (left), and typical synoptic charts associated with each type (based on composites of all cases), including surface pressure (centre) and geopotential height at $500 \mathrm{hPa}$ (right). 


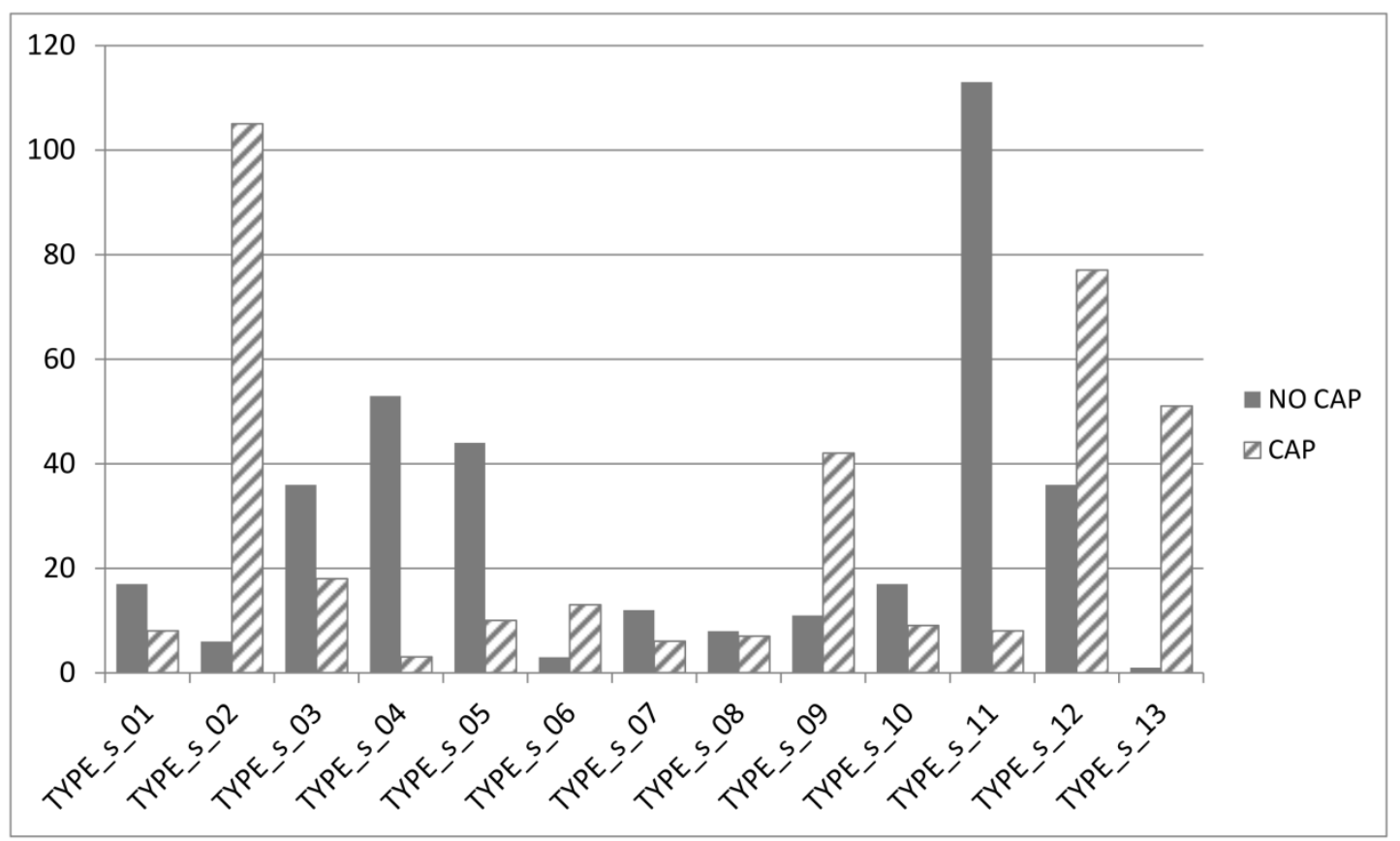

Figure 4. Number of CAP days (dashed) and no-CAP days (diagonal lines) for each type of the new classification. In nearly all cases either CAP or no-CAP is dominant.

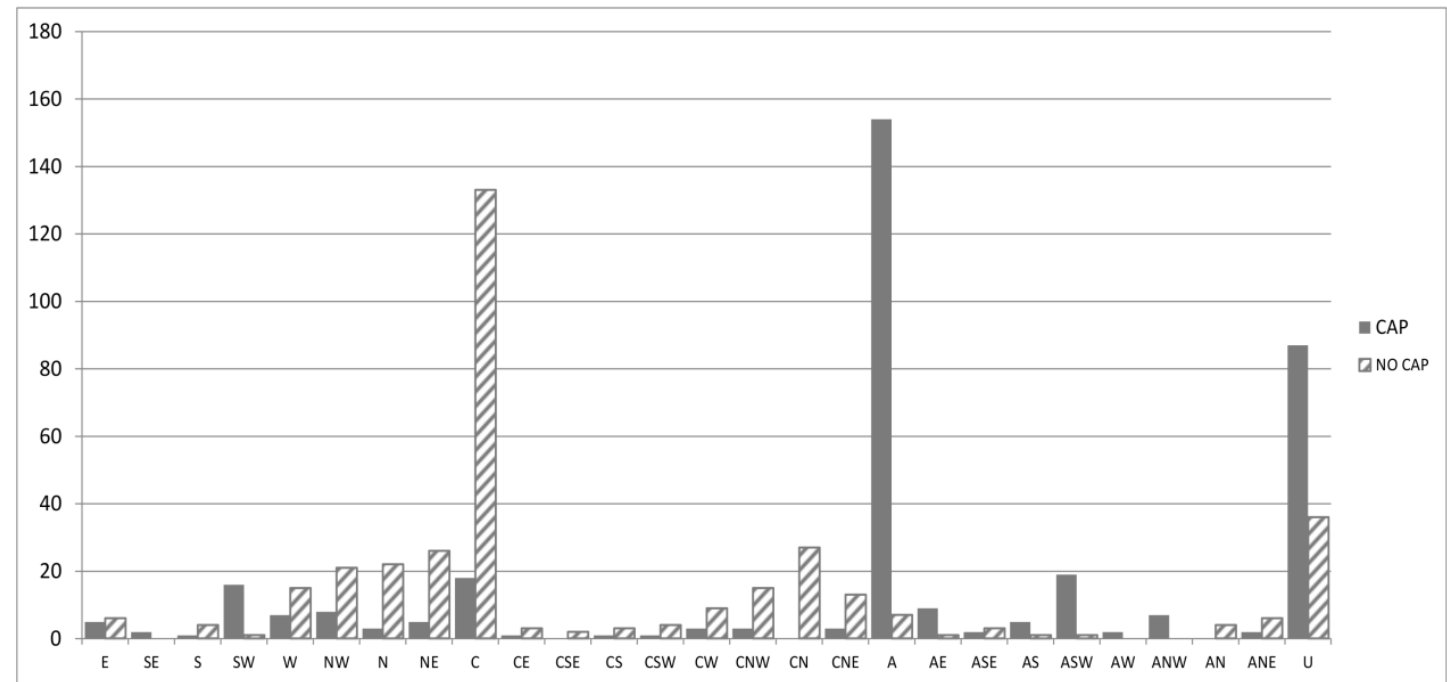

Figure 5. Number of CAP days (dashed) and number of no-CAP days (diagonal lines), for the original Jenkinson Collison classification based on surface pressure alone. 